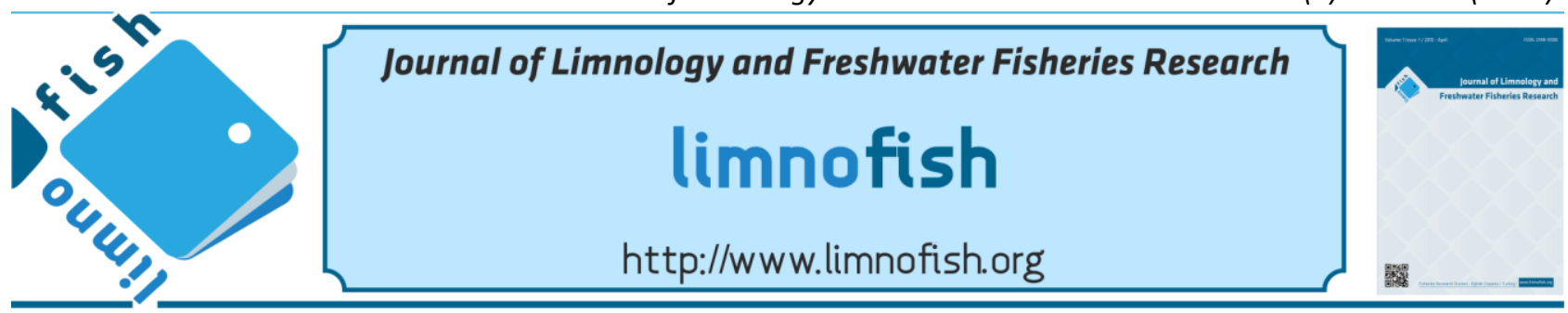

\title{
Natural and Non-natural Distribution of African Catfish Clarias gariepinus (Burchell, 1822) in Turkey
}

\author{
Funda TURAN*, Cemal TURAN \\ Iskenderun Technical University, Faculty of Marine Sciences and Technology, 31200, Iskenderun-Hatay-Turkey
}

\begin{abstract}
A B STRACT
African catfish, Clarias gariepinus (Burchell, 1822) is a widespread freshwater species found in the Middle East, and throughout Central and South Africa. C. gariepinus, inhabits natural lakes, fishponds, streams, and natural ponds in both deep and shallow waters. C. gariepinus is naturally found in the Asi, Seyhan, Ceyhan, Goksu Rivers. It was reported that $C$. gariepinus was translocated to the Aksu River by General Directorate of State Hydraulic Works. African catfish has increasing commercial importance in fisheries and aquaculture in Turkey. A recently introduced population of $C$. gariepinus has established in the Sakarya River (Eskişehir) due to aquaculture purposes in the north part of the Turkey. C. gariepinus introduction has negative effects on macro invertebrate community that was reflected by decrease in diversity, richness and biomass. There is also community-level impact of introduction that results variation in macro invertebrate composition in the rivers. Stomach contents of $C$. gariepinus basically rely on Pisces, Arthropod, Mollusca and plant materials to a considerable extent. Therefore, introduction of $C$. gariepinus in dams, rivers and lakes can cause food competitions with native fish and make irreversible changes in the fish community and cause loses of native fish. The present paper reviews published literature, reports and working papers about distribution and management of $C$. gariepinus in Turkey's reservoirs.
\end{abstract}

\section{ARTICLE INFO}

REVIEW

$\begin{array}{lll}\text { Received } & : 18.06 .2016 \\ \text { Revised } & : 15.11 .2016 \\ \text { Accepted } & : 14.12 .2016 \\ \text { Published } & : 23.12 .2016\end{array}$

DOI: 10.17216/LimnoFish.280413

* CORRESPONDING AUTHOR

funda.turan@iste.edu.tr

Tel : +903266141693

Fax: +903266141866

Keywords: African catfish, Clarias gariepinus, distribution, negative effects

\begin{abstract}
Karabalık Clarias gariepinus (Burchell, 1822)'un Türkiye'deki Doğal ve Doğal Olmayan Dağılımı
Öz: Karabalık Clarias gariepinus (Burchell, 1822), Güney Afrika, ve Orta Doğu'da geniş bir dağılım gösteren bir tatlısu türüdür. C. gariepinus, doğal göllerde, havuzlarda, akarsularda hem sığ hem de derin bölgelerde doğal yaşam alanlarına sahiptir. C. gariepinus'un Türkiye'deki doğal yayılım alanları Asi, Seyhan, Ceyhan ve Göksu nehirleridir. Daha sonraları bu türün DSI tarafından Aksu Nehri'ne aşılandığ rapor edilmiştir. Karabalık, Türkiye'de gerek avcılık gerekse yetiştiricilik açısından ekonomik bir değere sahiptir. Yetiştiricilik amaçlı Türkiye'nin kuzey bölgesine götürülen Karabalık Sakarya Nehri’nde (Eskişehir) zamanla doğal bir populasyon oluşturmuştur. C. gariepinus, çeşitlilik, bioması azaltarak makro omurgasız kommünitesi üzerinde olumsuz bir etkiye neden olmaktadır. C. gariepinus'un mide içeriği incelendiğinde başlıca balık, Arthropoda ve Mollusca ile beslendiği, bitkisel materyalinde çok fazla tüketildiği tespit edilmiştir. Bu nedenle C. gariepinus, giriş yaptığı göl, gölet ve nehirlerdeki yerli türlerle besin rekabetine girebilir ve bu da zamanla yerli balık popülasyonları üzerinde geri dönüşü olmayan değişikliklere ve türlerin kaybına neden olabilir. Bu çalışmada, Türkiye'deki tatlısu kaynaklarında yaşayan C. gariepinus 'un dağılımı ve yönetimi hakkında yapılmış olan çalışmalar, raporlar ve veriler değerlendirilmiştir.
\end{abstract}

Anahtar kelimeler: Karabalık, Clarias gariepinus, dağılım, olumsuz etkiler

How to Cite

Turan F, Turan C. 2016. Natural and non-natural distribution of African Catfish Clarias gariepinus (Burchell, 1822) in Turkey. LimnoFish. 2(3): 173-177. doi: 10.17216/LimnoFish.280413

\section{Introduction}

Family Clariidae at present consists of 14 genera, which comprise 92 species distributed in Africa and South-East Asia (Teugels 1986). African catfish, Clarias gariepinus Burchell, 1822 is of great commercial importance both in fisheries and aquaculture. C. gariepinus is a native species of Africa and has drawn attention of aquaculturists because of its biological attributes that include faster growth rate, resistance to diseases and possibility of high stocking density (Lal et al. 2003). It has an almost Pan African distribution (absent from 
Maghreb, the upper and lower Guinea, the Cape province, probably Nogal province), and also naturally occurs Jordan, Israel, Lebanon, Syria and southern Turkey (Teugels 1996). C. gariepinus inhabits natural lakes, fishponds, streams, and natural ponds in both deep and shallow waters (Figure 1). This fish has pseudo-lungs, a long body, high growth rate and a remarkable capacity to live in stagnant environments and adapt easily to new environments (Mwebaza-Ndawula 1984). In natural environments, the reproduction of African catfish $C$. gariepinus is associated with the rainy season, and individuals can reach up to $1.5 \mathrm{~m}$ in total length (Yalçın et al. 2001a). In its natural range, it is omnivorous (Yalçın et al. 2001a), and exhibits seasonal reproduction with high fecundity (Yalçın et al. 2001b), Its reproduction is seasonal with gonadal maturation associated to periods of flooding. The maturation process is influenced by changes in water temperature and photoperiod, but the increase of water level is the principal factor for their reproduction (Yalçın et al. 2001b; De Graaf et al. 1995).

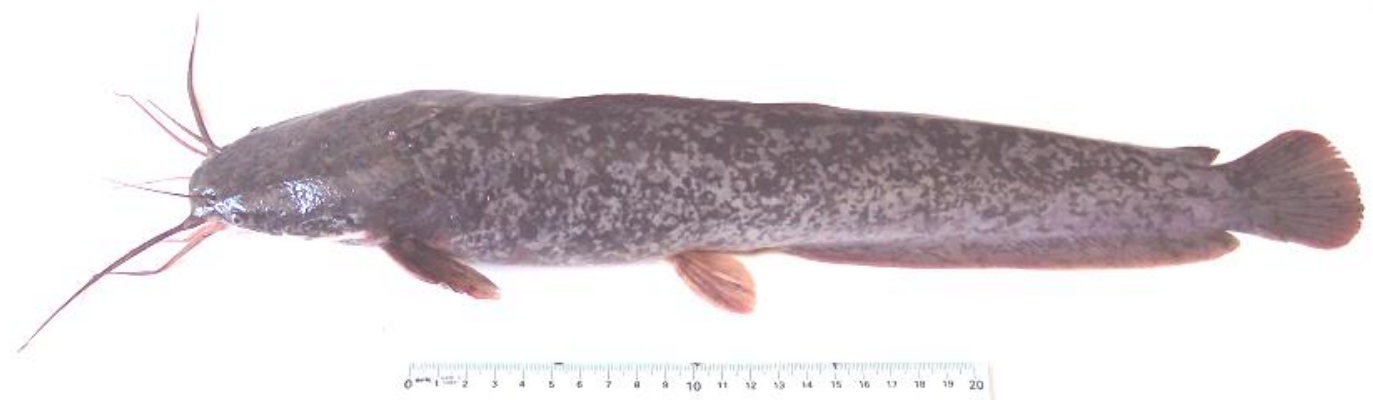

Figure 1. A general view of African catfish Clarias gariepinus from the Asi River (photo by F.Turan).

\section{Distribution in Turkey}

C. gariepinus is naturally found in the Asi, Seyhan, Ceyhan, Goksu Rivers (Geldiay and Balık 1988). It was reported that $C$. gariepinus was translocated to the Aksu River by D. S. İ. (General Directorate of State Hydraulic Works) (Balık 1988; Küçük and Ikiz 2004). Furthermore,
C. gariepinus was translocated to the Sakarya River in the north part of the Turkey for the purposes of scientific studies (Erençin 1978) (Figure 2).

The general distribution and extension of C. gariepinus in Turkish Rivers are summarised according to relevant studies as given in Table 1.

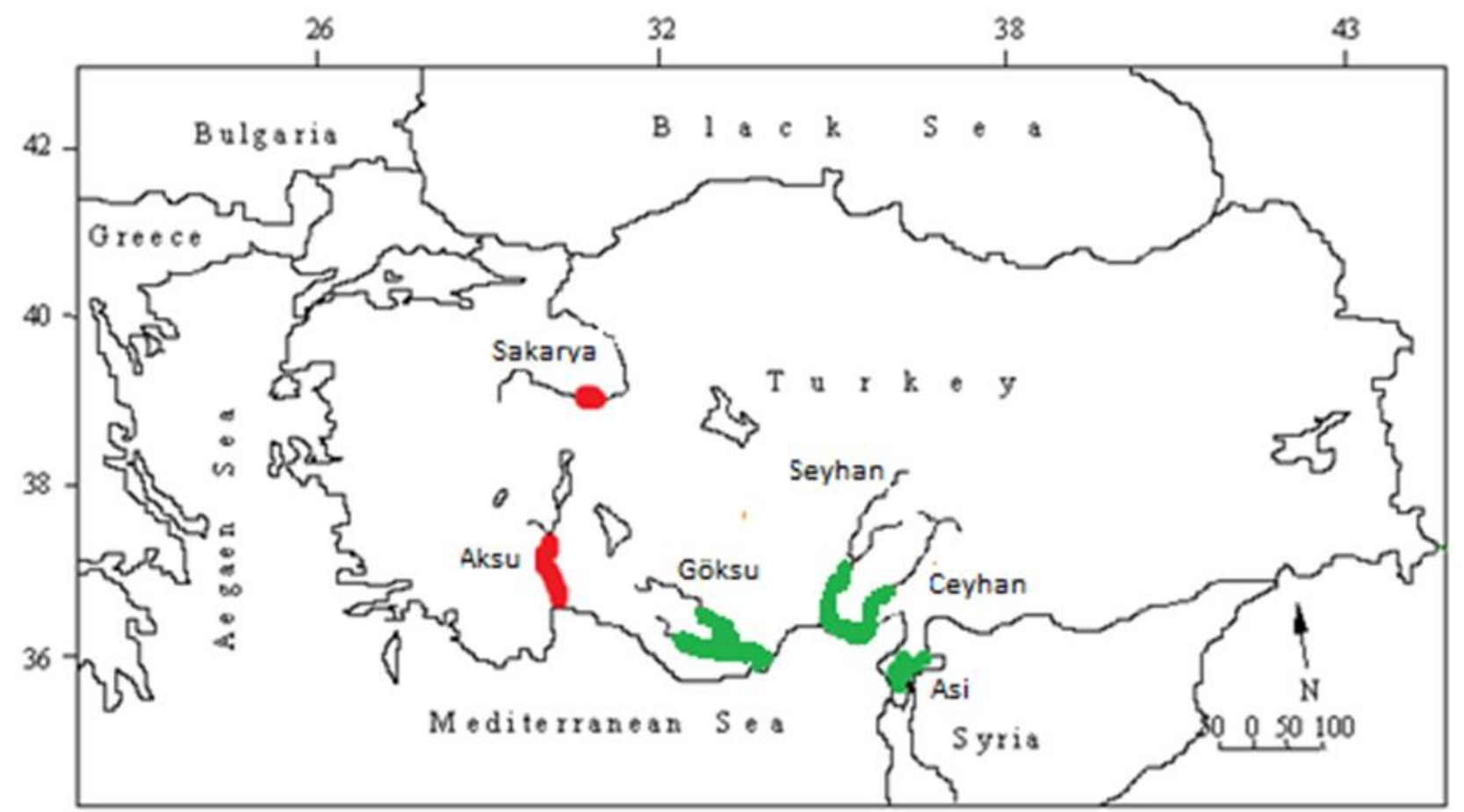

Figure 2. Natural (green coloured) and non-natural (red coloured) distribution of Clarias gariepinus in Turkish freshwaters. 
Table 1. Data on distribution of Clarias gariepinus from Turkish rivers.

\begin{tabular}{|c|c|c|c|c|c|}
\hline River & Locality, province & Specimens & $\begin{array}{l}\text { Range of total } \\
\text { length }(\mathbf{c m})\end{array}$ & Fishing method & References \\
\hline \multirow[t]{3}{*}{$\begin{array}{l}\text { Asi } \\
\text { (Orontes) }\end{array}$} & $\begin{array}{l}\text { Büyük Karaçay } \\
\text { stream of the River } \\
\text { Orontes }\end{array}$ & 56 & - & $\begin{array}{l}\text { Gill nets, cast nets and } \\
\text { Electroshocker }\end{array}$ & $\begin{array}{l}\text { (Özcan and Altun } \\
\text { 2015) }\end{array}$ \\
\hline & Orontes river & 4 & - & $\begin{array}{l}\text { Electroshocker, small hand } \\
\text { net and gill nets }\end{array}$ & (Özcan 2013) \\
\hline & $\begin{array}{l}\text { Güzelburc, Gölbası, } \\
\text { Samandağ }\end{array}$ & 523 & $25.05-53.66$ & Nets $(38 \times 38 m m-54 \times 54 m m)$ & $\begin{array}{l}\text { (Yalçın et al. } \\
\text { 2001b) }\end{array}$ \\
\hline Seyhan & Seyhan & 2 & 40.0 & Gill nets, cast nets & (Alagöz2005) \\
\hline \multirow[t]{2}{*}{ Ceyhan } & Aslantas & 26 & $27.0-44.0$ & Gill nets, cast nets & $\begin{array}{l}\text { (Yeşilbudak et al. } \\
\text { 2013) }\end{array}$ \\
\hline & Gavur and Kumasir & 7 & 22.84-14.98 & Electroshocker & (Kara et al. 2004) \\
\hline Göksu & Celtikci, Kurtuluş & 28 & $20.4-25.8$ & Gill nets & (Kaya 2009) \\
\hline & Silifke & 4 & $23.0-40.0$ & $\begin{array}{l}\text { Electroshocker, } \\
\text { Gill nets, trammel nets, seine } \\
\text { nets and cast nets. }\end{array}$ & (Küçük et al. 2007) \\
\hline Aksu & Serik & 14 & $12.0-38.0$ & $\begin{array}{l}\text { Electroshocker, Gill nets, } \\
\text { trammel nets, seine nets, cast } \\
\text { nets }\end{array}$ & $\begin{array}{l}\text { (Küçük and Ik1z } \\
\text { 2004) }\end{array}$ \\
\hline Sakarya & Çifteler Pond & High density & - & Electroshocker, gill nets & (Emiroğlu 2011) \\
\hline & Ahiler & High density & - & $\begin{array}{l}\text { Roller fishhook and scoop } \\
\text { net }\end{array}$ & (Emiroğlu 2011) \\
\hline
\end{tabular}

C. gariepinus has increasing commercial importance in fisheries and aquaculture in Turkey (Turan and Gürağaç 2014). A recently introduced population of $C$. gariepinus was established in the Sakarya River (Eskisehir) due to aquaculture purposes in the North part of the Turkey (Turan et al. 2005; Emiroğlu 2011). C. gariepinus has recently begun to threaten the wetland ecology in the Sakarya River basin by demonstrating a high level of adaptation to its new habitat (Emiroğlu, 2011).

The food variety of $C$. gariepinus is broad in natural environments. $C$. gariepinus feed on arthropods, molluscs, fish, reptiles, amphibians and plants (Yalçın et al. 2001b; Bruton 1979). Toleration of large environmental variation of $C$. gariepinus, e.g. of temperature and dissolved oxygen, leads to rapid acclimation to new environments. The wide prey options of $C$. gariepinus associated with its ability to adapt to different ecosystems facilitate its fast growth and air breathing capability, partly explains the wide dispersal area (Rabelo and Soares 2014). Owing to its enormous potential as an aquaculture fish during the $1990 \mathrm{~s}$, cultivation of $C$. gariepinus spread throughout Europe, Asia and Latin America (Verreth et al. 1993; Vitule et al. 2006). The fish quickly finds its way to nearby natural waters, mostly through river flooding and escapes from aquaculture ponds (Vitule et al. 2006). Because of its prolific predatory nature (Lal et al. 2003; Amin et al. 2009), competition for food and ability to alter food web structure (Khan and Panikkar 2009), and introgression with wild populations (Na-Nakorn 1999; Peh 2010), C. gariepinus became a potential threat to many of the native freshwater fishes in its regions of introduction. C. gariepinus was also reported to exacerbate habitat degradation and the spread of diseases and parasites (Booth et al. 2010).

Risk assessments under the European Commission (EC) Council Regulation No 708/2007 concerning the use of alien and locally absent species 
in aquaculture (ASR), the European Non-native Species in Aquaculture Risk Assessment Scheme (ENSARS) are briefly summarised, and the "Organism" module is applied to the 24 species listed in ASR's Annex IV. For the 'Risk of Introduction' section of the "organism" module, African catfish, Clarias gariepinus, was attributed to the highest score, followed by Japanese clam (Ruditapes philippinarum) and common carp (Cyprinus carpio) (Copp et al. 2014). Tarkan et al. (2014) also assessed the invasive potential of introduced non-native and translocated fishes in Turkey (Anatolia and Thrace) by applying the Fish Invasiveness Screening Kit (FISK), a risk identification tool for freshwater fishes that $C$. gariepinus was evaluated as translocated native invasive species with a mean value of calibration score 25.8 , high risk species.

\section{Conclusion}

It is important to determine and monitor the extent of spread of $C$. gariepinus in Turkey and control its impact on native fish and fisheries because it is a top predator that reaches a large size and can withstand extreme environmental conditions. Also, prolific predatory nature and high food competitional ability of $C$. gariepinus are potential threat to many of the native freshwater fishes in its regions of introduction. Therefore, a monitoring programme should be developed to verify if $C$. gariepinus is already established in relevant environment and its impacts on the native fish community should be revealed, and methods should be developed to control its expansion. Such information can contribute to the development of management plans that aims to minimize possible impacts of this species. Such plans must include increasing the awareness of this invasive species by scientists, farmers, fishermen, legislators and general public, as well as a rigorous application of existing laws.

\section{References}

Alagöz S. 2005. Determination of Ichthyofauna in the Seyhan Dam Lake (Adana) [Master's Thesis]. University of Çukurova, Adana, 85 pp. [in Turkish]

Amin M N, Ali M Y, Salequzzaman M. 2009. "Identification and impact analysis of invasive species: A case study in the Mongla sea port area of Bagerhat district of Bengladesh." Daffodil International University J. Sci. and Technol. 4: 35-41.

Balık S. 1988. The zoogeographical and systematical on freshwater fish in Mediterrenaen region in Turkey, Doğa T. Zool. Der., 12 (2):156-179. [in Turkish]

Booth A J, Traas G R L, Weyl O L F. 2010. "Adult African sharptooth catfish, Clarias gariepinus, population dynamics in a small invaded warm-temperate impoundment." Afr Zool. 45: 299-308. doi: 10.3329/diujst.v4i1.4353
Bruton M. 1979. "The food and feeding behaviour of Clarias gariepinus (Pisces: Clariidae) in Lake Sibaya, South Africa, with emphasis on its role as a predator of cichlids." The Transactions of the Zoological Society of London 35(1): 47-114. doi: 10.1111/j.1096-3642.1979.tb00057.x

Copp G H, Godard M J, Russell I C, Peeler E J, Gherardi F, Tricarico E, Miossec L, Goulletquer P, Almeida D, Britton J R, Vilizzi L, Mumford J, Williams C, Reading A, Rees E M A, Merino-Aguirre R. 2014. A Preliminary Evaluation of the European Non-Native Species in Aquaculture Risk Assessment Scheme Applied to Species Listed on Annex IV of the EU Alien Species Regulation. Fish Manag Ecol. 1-9. doi: 10.1111/fme.12076

De Graaf G, Galemoni F, Banzoussi B. 1995. "The artificial reproduction and fingerling production of the African catfish Clarias gariepinus (Burchell, 1822) in protected and unprotected ponds." Aquac Res. 26: 233-242.

Emiroglu O. 2011. “Alien fish species in upper Sakarya River and their distribution." Afr J Biotechnol. 10(73): $16674-16681$.

Erençin Z. 1978. Ankara Üniversitesi Veteriner Fakültesinin Çifteler Sakaryabaşı'ndaki Yeni Uygulama İstasyonunda Kültür Balıkçılığı Yönünden Önemli Ilımlı Balıklarının Yetiştirilmesi Olanakları Üzerinde Görüşler, Ankara University Journal of Faculty of Veterinary Medicine 2(25): 307-314.

Geldiay R, Balik S. 1988. Freshwater Fishes of Turkey. I. Edition. Ege University Publications, No: 97, Izmir, Turkey. 520p. [in Turkish]

Kara C, Alp A, Erer M. 2004. Distribution of Fish Fauna on Upper and Middle River Basin in Ceyhan Region, University of Kahramanmaraş Sütcü Imam, Presidency of Research Projects and The Management Unit, Kahramanmaraş, 2004. [in Turkish]

Kaya F. 2009. Karyology of some economically important fishes living in the Göksu River. Phd Thesis Universtiy of Mersin, Mersin, 118 pp. [in Turkish]

Khan M F, Panikkar P. 2009. "Assessment of impacts of invasive fishes on the food web structure and ecosystem properties of a tropical reservoir in India." Ecol. Model. 220: 2281-2290.

Küçük F, Ikiz R. 2004. "Fish fauna of streams discharging to the Antalya Bay." Turkish J Aqua Sci. 21(3-4): 287-294.

Küçük F, Gümüş E, Gülle I, Güçlü S S. 2007. “The Fish Fauna of the Goksu River (Türkiye) Taxonomic and Zoogeographic Features." Turk J Fish Aquat Sci. 7: 53-63.

Lal K K, Singh R K, Mohindra V, Singh B, Ponniah A G. 2003. "Genetic makeup of exotic catfish, Clarias gariepinus in India.” Asian Fish. Sci. 16: 229-234.

Mwebaza-Ndawula L. 1984. "Food and feeding habits of Clarias mossambicus from four areas in the Lake Victoria basin, East Africa." Env. Biol. Fish. 10:69-76. doi: 10.1007/BF00001663 
Na-Nakorn U. 1999. Genetic factors in fish production. A case study of the catfish, Clarias, pp. 175-187. In: Mustafa, S. (ed.). Genetics in Sustainable Fisheries Management. Fishing News Books, Malden MA.

Ozcan G. 2013. A contribution to knowledge of the freshwater fish of Orontes River, Hatay, Turkey. Proc Int Acad Ecol Environ Sci., 3(2), 143-147.

Ozcan G, Altun A. 2015. Ichthyofauna and Its Conservation Status of Büyük Karaçay Stream, Hatay, Turkey, Croatian Journal of Fisheries, 73, 63-66.

Peh K S.H. 2010. "Invasive species in south East Asia: The knowledge so far." Biodivers. Conserv. 19: 1083-1099.

Rabelo LB, Soares L S H. 2014. "Feeding interaction of the non-native african catfish Clarias gariepinus (Burchell, 1822) in Itanhém River Estuary, Bahia, Brazil.” Braz. J. Oceanogr. 62(3): 179-186.

Tarkan A S, Ekmekçi FG, Vilizzi L, Copp G H. 2014. Risk screening of non-native freshwater fishes at the frontier between Asia and Europe: first application in Turkey of the fish invasiveness screening kit. J Appl Ichthyol. 30(2), 392-398.

Teugels G G. 1986. "A systematic revision of the African species of the genus Clarias (Pisces; Clariidae)." Koninklijk Museum Voor Midden-Africa Tervuren, Belgie. Zool. Weten.-Ann. 247: 35-41.

Teugels G G. 1996. "Taxonomy, phylogeny and biogeography of catfishes (Ostariophysi, Siluroidei): an overview.” Aquat. Living Resour. 9: 9-34.
Turan C, Yalcin S, Turan F, Okur E, Akyurt I. 2005. "Morphometric comparisons of African catfish, Clarias gariepinus, populations in Turkey." Folia Zool. 54: 165-172.

Turan F, Gürağac R. 2014. "Induction of triploidy with caffeine treatment in the African catfish (Clarias gariepinus).” Iran J Fish Sci. 13(4): 1014-1020.

Verreth J, Eding EH, Rao GRM, Huskens F, Segner H. 1993. "A review of feeding practices, growth and nutritional physiology in larvae of the catfishes Clarias gariepinus and Clarias batrachus." J World Aquacult Soc. 24: 135-144. doi: 10.1111/j.1749- 7345.1993.tb00002.x

Vitule J R, Umbria S C, Aranha J M R. 2006. "Introduction of the African catfish Clarias gariepinus (Burchell, 1822) into Southern Brazil." Biol. Invasions. $8: 677-681$. doi: 10.1007/s10530-005-2535-8

Yalçın S, Akyurt I, Solak K. 2001a. "Stomach contents of the catfish Clarias gariepinus (Burchell, 1822) in the River Asi (Turkey).” Turk J Zool. 25: 461-468.

Yalçın S, Akyurt I, Solak K. 2001b. "Certain reproductive characteristics of the catfish (Clarias gariepinus Burchell, 1822) living in the River Asi, (Turkey)." Turk J Zool. 25: 453-460.

Yeşilbudak B, Duran S, Tunçsoy M, Erdem C. 2013. Some Morphometric Properties of Clarias gariepinus (Burchell, 1822) Population in Aslantaş Dam Lake (Osmaniye), J Aquacult Eng Fish Res., 9(2): 1-7. 